\title{
FRAUD PREVENTION IN THE PERSPECTIVE OF PROBITY AUDIT (THE CASE STUDY OF UNIVERSITY X)
}

\author{
Dhika Maha Putri ${ }^{1}$, Dian Syariati², Arisona Ahmad ${ }^{3}$ \\ Universitas Negeri Malang1,2, \\ Jl. Semarang No 5, 65145, Indonesia \\ Politeknik Negeri Jember ${ }^{3}$, \\ Jl. Mastrip No.164, 68121, Indonesia \\ e-mail :dhika.maha.fe@um.ac.id ${ }^{1}$
}

\begin{abstract}
Goods and services procurement in the university sector is a big chance towards fraud case occurrence. Corruption in the university environment resulted in state loss in the amount of two billion rupiahs. Therefore, The internal auditor of University X implements a probity audit as one effort to materialize the procurement system with low fraud possibility. The purpose of this study is to contribute to the understanding of fraud prevention using probity audits on goods and services procurement in the university sector. This research was carried out using a qualitative approach, with a case study method. The data collection was conducted by document analysis and interviews. The data obtained is then reduced, identified, and analyzed. The results conclude that the probity audit in University $X$ is a real-time audit which one conducted in the construction and maintenance stages. Based on the internal auditor evaluation result, a probity audit rated sufficiently to prevent fraud in the goods and services procurement process in the University X.
\end{abstract}

Keywords: Procurement; University; Fraud; Internal Auditor; Probity Audit

\section{Abstrak}

Pengadaan barang dan jasa di sektor perguruan tinggi merupakan peluang besar terjadinya kasus kecurangan. Korupsi di lingkungan perguruan tinggi mengakibatkan kerugian negara sebesar dua miliar rupiah. Oleh karena itu, auditor internal Universitas X menerapkan probity audit sebagai salah satu upaya untuk mewujudkan sistem pengadaan yang rendah resiko kecurangan. Tujuan dari penelitian ini adalah untuk mengkaji pencegahan kecurangan pada pengadaan barang dan jasa di sektor perguruan tinggi dengan menggunakan audit probity. Penelitian ini dilakukan dengan menggunakan pendekatan kualitatif, melalui metode studi kasus. Pengumpulan data dilakukan dengan analisis dokumen dan wawancara. Data yang diperoleh kemudian direduksi, diidentifikasi, dan dianalisis. Hasil penelitian menyimpulkan bahwa audit probity di Universitas X merupakan audit real-time yang dilakukan pada tahap konstruksi dan pemeliharaan. Berdasarkan hasil evaluasi auditor internal, probity audit dinilai cukup untuk mencegah terjadinya kecurangan dalam proses pengadaan barang dan jasa di Universitas X.

Kata kunci: Pengadaan; Universitas; Kecurangan; Auditor Internal; Audit Probity

\section{INTRODUCTION}

Murwanto (2012) said that the factors influencing the successful implementation of government tasks, both at the central and regional levels including state and regional companies, depending on the availability of work facilities and infrastructure according to needs. Therefore, in every APBN or APBD, there is always a budget for the procurement of facilities and infrastructure in the form of movable goods, services, and immovable goods. The availability of quality goods and services in the administration of the government will be very influential in improving public services. In an effort to obtain quality goods/services, procurement of goods/services must be done transparently 
Dhika Maha Putri, Dian Syariati dan Arisona Ahmad : Fraud Prevention In The Perspective Of Probity Audit (The Case Study Of University X)

through the open and fair competition so that the efficiency and effectiveness of procurement of goods/services can be achieved (Probity Audit Guidelines for Procurement of Goods and Services).

However, on the other side, based on a survey conducted by KPMG (Global Banking Fraud Survey - KPMG Indonesia, n.d.), shows that fraud increased during 20152018. The increased fraud is in accordance with the report issued by ACFE (Association of Certified Fraud Examiners) (2020 ACFE Report to the Nations, n.d.) in the Report to the Nation which reports that 2,504 acts of fraud have occurred in 125 countries with an average loss of USD 1,509,000. Goods and services procurement, especially in the university environment, is one of the points towards fraud case occurrence. Based on Indonesian Corruption Watch Report (Watch, 2017), it was found that corruption which occurred in the university places the second position of state loss which amount is 2 billion rupiahs. Corruption cases that occur in the public sector are more widely publicized in the media than in the private sector. This is because the impact of corruption by state officials has a direct impact on state finances (Inawati \& Sabila, n.d.). Tuanakotta (2010) said that the process of procuring goods and services is the main source of public leakage. Based on the type of case handled by the KPK (Corruption Eradication Commission), a large percentage of fraud occurred in the procurement of goods and services, amounting to $32 \%$ of all cases. This percentage does not include cases of bribery which may also relate to the procurement process of goods and services. Based on the Summary of Inspection Results (2019) issued by BPK (Badan Pemeriksa Keuangan Republik Indonesia, 2019), there are several types of goods and services procurement cases, namely (a) cases that are detrimental to state finances; (b) potentially detrimental to state finances, (c) lack of revenue; (d) violates administration; (e) inefficiency; and (f) inefficiency.

The importance of goods and services procurement activities in the organization creates an effort to implement procurement systems with a minimum of fraud through probity audits. A new audit method called real-time procurement audit is one of the government's alternatives to mitigate problems related to the procurement process for goods/services, especially fraud and irregularities. In the United States, such audits are known as pre-award audits (Earnhart \& Leonard, 2016). and in Australia, they are referred to as honesty audits (Whittle et al., 2014). Probity audit is one type of inspection of goods and services procurement. A probity audit refers to a review of the government related to the procurement process. A probity audit is a series of audit methods to ensure whether the procedures followed are procedures that are consistent with the right regulations and in accordance with the principles of openness and transparency (Ryan \& $\mathrm{Ng}$, 2002). The examination of the implementation of procurement of goods and services is intended to test and find out to what extent the rules and regulations governing the implementation of procurement of goods and services are complied with so that efforts to realize the principles of economy, efficiency, and effectiveness in the procurement of goods and services can be achieved (Murwanto et al., 2012). The Indonesian Development Finance Supervisory Agency (BPKP) states that "Probity is defined as integrity (integrity), truth (uprightness), and honesty (honesty)". 
Dhika Maha Putri, Dian Syariati dan Arisona Ahmad : Fraud Prevention In The Perspective Of Probity Audit (The Case Study Of University X)

It is the auditor's responsibility to audit financial statements in accordance with applicable regulations (International Standards on Auditing (ISA) 240, 2009). Therefore the probity process audit is furthermore implemented by the Internal Audit Office of university $X$ as one of the facilities to apply university management accountability. A university with the status of a Public Service Agency (BLU) has a dual function as a reporting entity and an accounting entity regarding its financial reporting (Setiawan \& Rasmini, 2021). As a reporting entity, BLU is required to disclose all use of resources to stakeholders. BLUs are required to prepare and report consolidated report finance as an accounting entity with an accounting entity under it. This study is based on the results of previous studies regarding the implementation of audit probity at the Inspectorate level. Probity audit even though it already has a strong foundation and adequate guidelines, in practice it is still difficult to implement. The things that encourage the lack of implementation of the audit probity in the government environment is due to the lack of human resources and adequate facilities and infrastructure (Legawa, 2016). Based on this background, the purpose of this study is to contribute to the understanding of fraud prevention using probity audits on goods and services procurement in the university environment.

\section{METHOD}

This research is a case study research. The study applied a descriptive qualitative data analysis method. The object of this research is University X. Data collection techniques used in this study are interviews and documentation studies. Interviews were conducted with parties related to the implementation of the probity audit at University $X$, i.e (a) Head of Division of the University X Internal Audit Office (HD); (b) Staff in the audit of the procurement of goods and services at University X (A1 and A2); (c) Head of Division University X Procurement and Logistics Center (N1) and (d) Commitment Officer (N2). The documentation study was carried out through an analysis of documents related to the implementation of the probity audit at University X, such as (a) Guidelines on Probity Audit of Goods and Services Procurement for APIP; (b) University X Internal Audit Office Procurement Audit Guidelines; (c) ) University X Internal Audit Office Goods and Services Procurement Audit Program; (d) Procurement Documents (PostQualification Auction) and (e) Monitoring Results Report.

Data analysis in qualitative research will take place simultaneously with other parts of the development of qualitative research, namely data collection and writing of findings. In data analysis, researchers need to "separate" data, a process that focuses on some data and ignores other parts (Creswell, 2010). Miles and Huberman in Sugiyono (2009), argued that the activities in qualitative data analysis are carried out interactively and take place continuously until they are finished so that the data is saturated. Activities undertaken in data analysis are data reduction, data presentation, and drawing conclusions and data verification. This research, using the technique of triangulation of sources and triangulation of methods, to carry out the validity test of research results. In addition, researchers will also conduct member checks to reduce bias.. 
Dhika Maha Putri, Dian Syariati dan Arisona Ahmad : Fraud Prevention In The Perspective Of Probity Audit (The Case Study Of University X)

\section{RESULT AND DISCUSSION}

The audit of goods and services at university $x$ uses Government Regulation Number 60 the Year 2008 and Indonesian Presidential Regulation Number 54 the Year 2010 as a legal basis. The implementation of the audit probity includes the selection of auditees following the Guidelines on Probity Audit of Goods and Services Procurement for APIP (Government Internal Control Apparatus). The guideline states that there are seven stages of the procurement process that can be audited using the probity approach, namely (a) planning of procurement of goods and services; (b) preparation for selecting suppliers of goods and services; (c) selection of suppliers of goods and services with postqualification; (d) selection of providers of goods and services with prequalification; (e) signing and executing consulting services for business entities and their use; (f) signing and implementation of construction contracts and their use; and ( $\mathrm{g}$ ) the signing and execution of contracts for the procurement of other goods and services and their use. Of the seven stages, probity audits can be carried out starting from the process of identifying needs until the goods and services are utilized or only a few selected stages of a process of procurement of goods and services.

Probity audit at university $\mathrm{x}$ is implemented in the construction procurement package especially at the contract implementation and maintenance stages because that stage is considered to have a high risk (Risk-Based Audit). Risks in the implementation phase of the contract include: (a) the limited number of Commitment Making Officials (PPK); (b) there are PPK who also serve as structural officials; (c) the complex nature of construction work and requires understanding in certain fields; (d) limited audit time; and (e) inadequate administration. On the other hand, the warranty 6 months after PHO (Provisional Hand Over) at the maintenance (monitoring) stage is often not maximized by the user (university $\mathrm{x}$ ). This results in damage claims that cannot be filed with the provider so the user must bear the cost of repairing the damage. Departing from risk considerations, audit office university $\mathrm{x}$ implemented a probity audit in accordance with the steps set out in the Guidelines for the Probity Audit of Goods and Services Procurement for APIP.

The implementation of the probity audit at university $\mathrm{x}$ is divided into several stages, namely (a) the preparation stage; (b) the implementation stage; and (c) the reporting stage. The preparatory stage is the stage where the auditor carries out audit socialization, preparation of the audit charter and human resource planning (auditor). The appointment of an auditor who will conduct a probity audit at university $\mathrm{x}$ is based on competency (adequacy of education) and the type of work to be audited. In this case, the auditor's competence needed is the auditor with a civil engineering background. Civil engineering competence is needed because the assignment of probity to the construction procurement package is quite complicated and involves a lot of knowledge and technical terms.

The next stage in probity audit is the implementation stage where the auditor carries out the determination of the auditee (procurement package to be audited), conducts initial talks with the auditee and determines the audit method according to field conditions. Then, the last stage is the stage where the auditor carries out the reporting of 
Dhika Maha Putri, Dian Syariati dan Arisona Ahmad : Fraud Prevention In The Perspective Of Probity Audit (The Case Study Of University X)

the final audit results in the form of a presentation of findings and recommendations. The results of the probity audit will be immediately submitted to the evaluation meeting which is held every two weeks. If the results of the probity find findings, the audit office will ask the provider to immediately follow up on it. This follows up is monitored by the auditor at the next evaluation meeting. Therefore, the results of a probity audit carried out by the audit office can be an evaluation and warning tool for the construction procurement process. Apart from being presented at the evaluation meeting, the results of the monitoring will also be compiled in the LHM (Report on Monitoring Results), as a final report. This monitoring results report contains audit office findings during the monitoring process which are not followed up to a certain time limit. Monitoring reports will be given to the chancellor, as the highest leader of the university.

The fundamental difference between the probity audit and post-audit is in terms of implementation time. Post audits are conducted when the procurement activities are completed, while the probity audit is inherent in the procurement process itself. The identification of audit sampling becomes important in probity because of the real-time principles in conducting audits. The Guidelines for the Probity Audit of Goods and Services Procurement for APIP include several methods that can be used in conducting probity audits, including (a) desk audits, which means the step of reviewing regulations and documents; (b) field audit or field inspection; (c) benchmarking, which is the process of comparing with existing references; and (d) the use of experts. The guideline also states that probity auditors are given the authority to fully access all records, personnel, then observe meetings, conduct field visits and make copies of relevant documents needed.

The implementation of a probity audit at university $x$ has several obstacles in terms of human resources (HR) and implementation time. Probity audit, especially in construction procurement is a type of audit that is quite complicated because many technical matters must be known by the auditor. This certainly requires an auditor with an appropriate background such as an auditor from the civil engineering department. On the other hand, although most university $x$ auditors already have procurement certifications, it does not mean that they can comprehend technical matters in depth. That is quite difficult because in the audit office only a few auditors have civil engineering backgrounds. On the other hand, probity audit assignments require auditors to always be present at monitoring meetings. This makes the probity audit assignment time tends to be longer than other types of audits. On the other hand, the type of audit conducted by the audit office is not just a procurement audit. There are other types of audits such as performance audits, financial audits, system audits and audits by request. Therefore, the allocation of implementation time for the probity audit is very limited and only implemented at the stage of implementing certain procurement packages. Based on these limitations it can be concluded that in carrying out a probity audit, sufficient human resources are needed both in terms of qualitative (knowledge base) and quantitative (number of auditors).

The tool that can be used to prevent fraud is through and starting from internal control (Tuanakotta, 2010). Internal control is an important part of an organization's efforts to prevent fraud. A comprehensive and fully implemented monitoring system of 
Dhika Maha Putri, Dian Syariati dan Arisona Ahmad : Fraud Prevention In The Perspective Of Probity Audit (The Case Study Of University X)

internal control is essential for preventing and detecting losses due to fraud. Probity audit is technically expected to be able to mitigate risks that have the potential to become findings as internal controls function in the organization.

"Risks if left untreated can be the auditor's findings. Therefore, monitoring activities in probity is how a risk can be mitigated (controlled) so that during implementation there is no potential for findings". (HD)

Probity audits in university $x$ can prevent fraud in the procurement of goods and services through the auditee selection process which has been prioritized from the beginning with a high risk. This is in line with the results of research conducted by Capalbo \& Palumbo (2012), Doig (2014), Keerasuntonpong, Manowan, \& Shutibhinyo (2019), Silva (2016), and Westhausen (2017) conclude that the probability audit is effective in terms of preventing and detecting fraud because it is carried out in real-time when the process of procuring goods and services is carried out. This is an effort so that the procurement process can run according to the contract and does not cause potential findings or fraud.

"... and then for the Auditee selection, the monitoring process is not carried out on all procurement packages and not at all stages of procurement. Probity audits are carried out on procurement packages that have high risk. Other things such as the preparation of audit programs and the audit methods aimed at mitigating risk." (HD)

The preparation of programs and methods on audit probity is adjusted to the field conditions faced by the auditor so that the auditor can maximize his audit. The audit probability implemented by the university audit office $x$ makes the auditor have information about third parties (providers and supervisors) that is more relevant to the conditions on the ground. This information makes the auditor more aware of the results of work performed by third parties so that the risk of fraud can be mitigated.

Auditors spend the largest portion of their time planning and conducting audits to detect errors and fraud (Arens et al., 2012). Audits are very useful for entities to maintain consistency against efficiency and effectiveness that have been achieved so far, both entities in the sector commercial and public sector entities (Fransisca \& Aliya, 2019). Audits can be used to assess the extent to which entity managers work in accordance with actual provisions, standards, procedures, and work instructions. In addition, the audit can be used to determine the conditions of the work environment and discipline of the documents used. The process of monitoring in probity audits, in addition to preventing fraud, is also useful in detecting potential fraud. The use of a probity audit when compared to post-audit is relatively better in detecting fraud because the evidence of fraud has not been buried too long. Fraud perpetrators will have difficulty in changing evidence of fraud because the activities of the perpetrators will be monitored by the auditors in real-time. The monitoring process in the audit probity makes fraud that will occur or has already happened can be detected earlier so it does not cause greater losses for the organization. On the other hand, audit probity can increase the auditor's understanding of a procurement package. Thus, if a case occurs, an auditor's findings or fraud can respond and follow up on this quickly. Probity audit makes the gap to commit fraud can be minimized by auditing methods such as field observations because what is 
Dhika Maha Putri, Dian Syariati dan Arisona Ahmad : Fraud Prevention In The Perspective Of Probity Audit (The Case Study Of University X)

reported in the evaluation meeting, in documents and facts on the ground can be immediately known. Probity audits make the procurement system more transparent and accountable.

"The advantage of using probity audits in real-time, especially when there are problems in the field, auditors can immediately give advice. If there are still findings behind, the findings are not as much and as large as when using probity." (A2)

"The procurement package that is used as an audit sample has been monitored in real-time, already day by day. So the recommendations are in accordance with what is happening on the ground." (N1)

"Probity audits ensure that all procurement processes are well documented so that they are suitable to be matched with facts in the field. This matching result becomes the recommendation of the auditor." (A2)

\section{CONCLUSION}

The purpose of this study is to contribute to the understanding of fraud prevention using probity audits on goods and services procurement in the university environment. The theoretical implication of this research is that it can be used as one of the best practices in the application of probity audit, especially in the public sector. In the future, the practice of probity audit can be improved as an alternative audit method to mitigate the risk of fraud in the procurement of goods and services. In addition, practically this research can also be used as input in making government goods and services audit regulations. Probity audit is implemented in the construction procurement package, especially in the contract implementation and maintenance stages as the procurement process that is considered to have the highest risk. Based on this, it can be concluded that the probity audit at university $\mathrm{x}$ is conducted by a risk-based audit. Probity audit at university $x$ is attached in real-time to every process that occurs in the construction procurement package. Implementation of probity audit at university $\mathrm{x}$ has several limitations in terms of the number of auditors that can be assigned to the field. In addition, University's audit office uses probity audits to prevent and detect fraud on construction procurement packages. Fraud mitigation through probity audits is implemented in a way; (a) the auditee selection process is based on risk; (b) more comprehensive information about third parties (providers); (c) there is a real-time principle that can minimize the accumulation of evidence of fraud; and (d) monitoring attached to the procurement process.

\section{REFERENCES}

2010.Peraturan Presiden Nomor 54 tahun 2010 tentang Pengadaan Barang dan Jasa.

2017.Peraturan Badan Pemeriksa Keuangan No. 1 Tahun 2017 tentang Standar Pemeriksaan Keuangan Negara.

2020 ACFE Report to the Nations. (n.d.). 2020. Retrieved June 1, 2021, from https://www.acfe.com/report-to-the-nations/2020/ 
Dhika Maha Putri, Dian Syariati dan Arisona Ahmad : Fraud Prevention In The Perspective Of Probity Audit (The Case Study Of University X)

Arens, A. A., Elder, R. J., \& Mark, B. (2012). Auditing and assurance services: an integrated approach. Boston: Prentice Hall.

Capalbo, F., \& Palumbo, R. (2012). The imperfect match of public accountability of stateowned enterprises and private-sector-type financial reporting: the case of Italy. Capalbo, Francesco and Palumbo, Riccardo, The Imperfect Match of Public Accountability of State-Owned Enterprises and Private-Sector-Type Financial Reporting: The Case of Italy, Australasian Accounting Business and Finance Journal, 7(4), 2013.

Creswell, J. W. (2010). Research design pendekatan kualitatif, kuantitatif, dan mixed. Yogyakarta: Pustaka Pelajar.

Doig, A. (2014). Roadworks ahead? Addressing fraud, corruption and conflict of interest in English local government. Local Government Studies, 40(5), 670-686.

Earnhart, D., \& Leonard, J. M. (2016). Environmental audits and signaling: The role of firm organizational structure. Resource and Energy Economics, 44, 1-22.

Fransisca, S., \& Aliya, S. (2019). IMPLEMENTASI AUDIT MUTU INTERNAL ISO 9001 PADA SISTEM MANAJEMEN RSUD KAYU AGUNG KABUPATEN OKI. EL MUHASABA: Jurnal Akuntansi (e-Journal), 10(1), 30-44.

Global Banking Fraud Survey - KPMG Indonesia. $\quad$ (n.d.). 2019. https://home.kpmg/id/en/home/insights/2019/07/the-multi-faceted-threat-offraud.html

IHPS BPK SEMESTER II, 2018. (2019). Konsep Persetujuan.

Inawati, W. A., \& Sabila, F. H. (n.d.). Pencegahan Fraud: Pengaruh Whistleblowing System, Government Governance dan Kompetensi Aparatur Pemerintah. E-Jurnal Akuntansi, 31(3).

International Standards on Auditing (ISA) 240. (2009). International Standard on Auditing 240 the Auditor' S Responsibilities Relating To Fraud in an Audit of Financial Statements. 155-197.

Keerasuntonpong, P., Manowan, P., \& Shutibhinyo, W. (2019). Reforming government public accountability: the case of Thailand. Journal of Public Budgeting, Accounting $\mathcal{E}$ Financial Management.

Legawa, P. (2016). Analisis Peranan Inspektorat Daerah Dalam Pencegahan dan Pendektesian Fraud pengadaan Barang/jasa Pemerintah Daerah. Universitas Gadjah Mada.

Murwanto, R., Budiarso, A., \& Ramadhana, F. H. (2012). Audit Sektor Publik Suatu Pengantar Bagi Pembangunan Akuntabilitas Instansi Pemerintah. Jakarta: LPKPAP.

Ryan, C., \& Ng, C. (2002). Australian auditors-general involvement in probity auditing: evidence and implications. Managerial Auditing Journal. 
Dhika Maha Putri, Dian Syariati dan Arisona Ahmad : Fraud Prevention In The Perspective Of Probity Audit (The Case Study Of University X)

Setiawan, I. M. H., \& Rasmini, N. K. (2021). Penerapan Standar Akuntansi Pemerintahan, Sistem Pengendalian Internal dan Kualitas Pegawai Pada Kualitas Laporan Keuangan. E-Jurnal Akuntansi; Vol 31 No 5 (2021). https://doi.org/10.24843/EJA.2021.v31.i05.p19

Silva, P. (2016). 'A poor but honest country': Corruption and probity in Chile. Journal of Developing Societies, 32(2), 178-203.

Sugiyono, M. P. P., \& Kuantitatif, P. (2009). Kualitatif, dan R\&D, Bandung: Alfabeta. Cet. VII.

Tuanakotta, T. M. (2010). Audit forensik dan audit investigatif. Jakarta: Salemba Empat.

Watch, I. C. (2017). Laporan Akhir Tahun ICW. Jakarta: Antikorupsi. Org.

Westhausen, H.-U. (2017). The escalating relevance of internal auditing as anti-fraud control. Journal of Financial Crime.

Whittle, A., Carter, C., \& Mueller, F. (2014). 'Above the fray': Interests, discourse and legitimacy in the audit field. Critical Perspectives on Accounting, 25(8), 783-802. 